\title{
Algoritma K-Nearest Neighbor Untuk Menentukan Kelayakan Keluarga Penerima Bantuan Pangan Non Tunai (Studi Kasus: Kelurahan Karya Jaya)
}

\author{
Sastri Yani ${ }^{1}$, Fithri Selva Jumeilah², Muhamad Kadafi ${ }^{3}$ \\ 1,2.3Program Studi Sistem Informasi, UIN Raden Fatah Palembang, Indonesia \\ Email: 1sastriyani_1635400127@radenfatah.ac.id, 2fithriselvajumeilah@radenfatah.ac.id, \\ 3kadafi_uin@radenfatah.ac.id
}

\begin{abstract}
Non-cash Food Assistance (BPNT) is food social assistance in the form of non-cash. In its implementation, this program still encounters a number of obstacles, one of which is in the sub-optimal distribution of aid in several regions, including Karya Jaya Village. This is because the Ministry of Social Affairs is not optimal in determining BPNT recipients. One way to solve this problem is by utilizing one of the data mining concepts, namely the classification technique with the K-Nearest Neighbor algorithm. Where KPM data previously only accumulated can be used as useful information, one of which is to predict the eligibility of BPNT recipients in the next period. The results of this research are in the form of information on the results of predictions of appropriate KPM as BPNT recipients in 2021 and Local Environmental Units (SLS) which are the most receiving regions. This information can be used as evaluation material for the Ministry of Social Affairs in determining the more targeted BPNT recipients. The prediction results of BPNT recipients in Karya Jaya Village in 2021 are 511 recipients with an accuracy rate of 75.79\%, 76.17\% Precision, 89.24\% Recall, and $82.19 \%$ F-measure. And it can be seen that the most BPNT recipient categories are in SLS RW 005, namely 74 recipients. Where there are variables that most influence, namely sta_kis.
\end{abstract}

Keywords: Feasibility, BPNT, Data Mining, K-Nearest Neighbor

\section{PENDAHULUAN}

Salah satu perkara mendasar yang menjadi pusat perhatian pemerintah diberbagai negara, termasuk Indonesia ialah tingkat kemiskinan yang tinggi. Untuk membantu meminimalkan tingkat kemiskinan tersebut, pemerintah mengadakan beberapa program bantuan, yaitu salah satunya program bantuan sosial untuk rakyat miskin dalam bentuk non tunai atau yang biasa disebut dengan Bantuan Pangan Non Tunai (BPNT) [1]. 
BPNT ini ialah bantuan sosial pangan dalam bentuk non tunai yang bersumber dari pemerintah, kemudian diserahkan kepada Keluarga Penerima Manfaat (KPM) melalui mekanisme account elektronik pada setiap bulannya yang akan digunakan hanya untuk membeli bahan pangan berupa telur dan beras di pedagang bahan pangan atau e-warong [2]. Dalam pelaksanaannya BPNT masih menemui sejumlah kendala salah satunya dalam hal penyaluran bantuan yang belum optimal di beberapa daerah, termasuk Kelurahan Karya Jaya. Dalam menjalankan program BPNT, banyak warga yang mengeluh karena tidak mendapat bantuan, sedangkan ada beberapa warga yang dianggap mampu justru mendapatkan bantuan. Sehingga timbul masalah pembagian bantuan sosial yang tidak merata dan tepat sasaran di lingkungan Kelurahan Karya Jaya. Hal ini disebabkan karena kurang optimalnya dalam penentuan penerima BPNT oleh Kementerian Sosial.

Salah satu cara untuk mengatasi permasalahan diatas ialah dengan memanfaatkan salah satu konsep data mining yaitu teknik klasifikasi. Data Mining ialah disiplin ilmu yang tujuan utamanya adalah untuk menemukan, menggali, atau menambang pengetahuan dari data atau informasi yang kita miliki. Klasifikasi ialah proses untuk memperoleh model atau aturan yang dapat mengklasifikasikan data baru yang belum pernah dipelajari dengan mempelajari sekumpulan data yang lama [3]. Teknik yang digunakan adalah dengan memanfaatkan data penerima BPNT lama yang nantinya akan digunakan sebagai data training yang digunakan untuk menguji data baru apakah data baru berhak menerima BPNT berdasarkan kemiripan atribut yang ada di data lama dengan data baru.

Sehingga dalam penelitian ini akan dilakukan proses pengolahan data menggunakan data mining untuk mengklasifikasi layak dan tidak layaknya menerima BPNT. Penggunaan algoritma yang tepat dapat meningkatkan keakuratan keputusan yang diambil. Metode klasifikasi algoritma K-Nearest Neighbor merupakan salah satu metode pengklasifikasian data yang memiliki konsistensi yang kuat, dengan cara mencari kasus dengan menentukan nilai jarak pada pengujian data testing dan data training berdasarkan nilai terkecil dari nilai ketetanggaan terdekat [4]. Algoritma ini memiliki beberapa kelebihan yaitu bahwa dia tangguh terhadap training data yang noise, lebih efektif dalam melakukan training data yang besar dan dapat menghasilkan data yang lebih akurat. Metode ini dapat melakukan klasifikasi terhadap objek berdasarkan data pembelajaran yang jaraknya paling dekat dengan objek tersebut [5].

Berdasarkan latar belakang di atas penulis tertarik untuk melakukan penelitian dengan judul "Algoritma K-Nearest Neighbor Untuk Menentukan Kelayakan 
Keluarga Penerima Bantuan Pangan Non Tunai (Studi Kasus : Kelurahan Karya Jaya)".

\section{METODOLOGI PENELITIAN}

\subsection{Metode Penelitian}

Metode penelitian yang digunakan dalam penelitian ini ialah metode penelitian kuantitatif dengan memanfaatkan metode data mining dan perhitungan algoritma K-Nearest Neighbor.

\subsection{Bahan Penelitian}

Dalam penelitian ini bahan yang digunakan untuk diolah menjadi acuan adalah data dari daftar kolektif hasil kuisioner PPLS (Program Perlindungan Sosial) Kelurahan Karya Jaya pada tahun 2017-2020.

\subsection{Tahapan Penelitian}

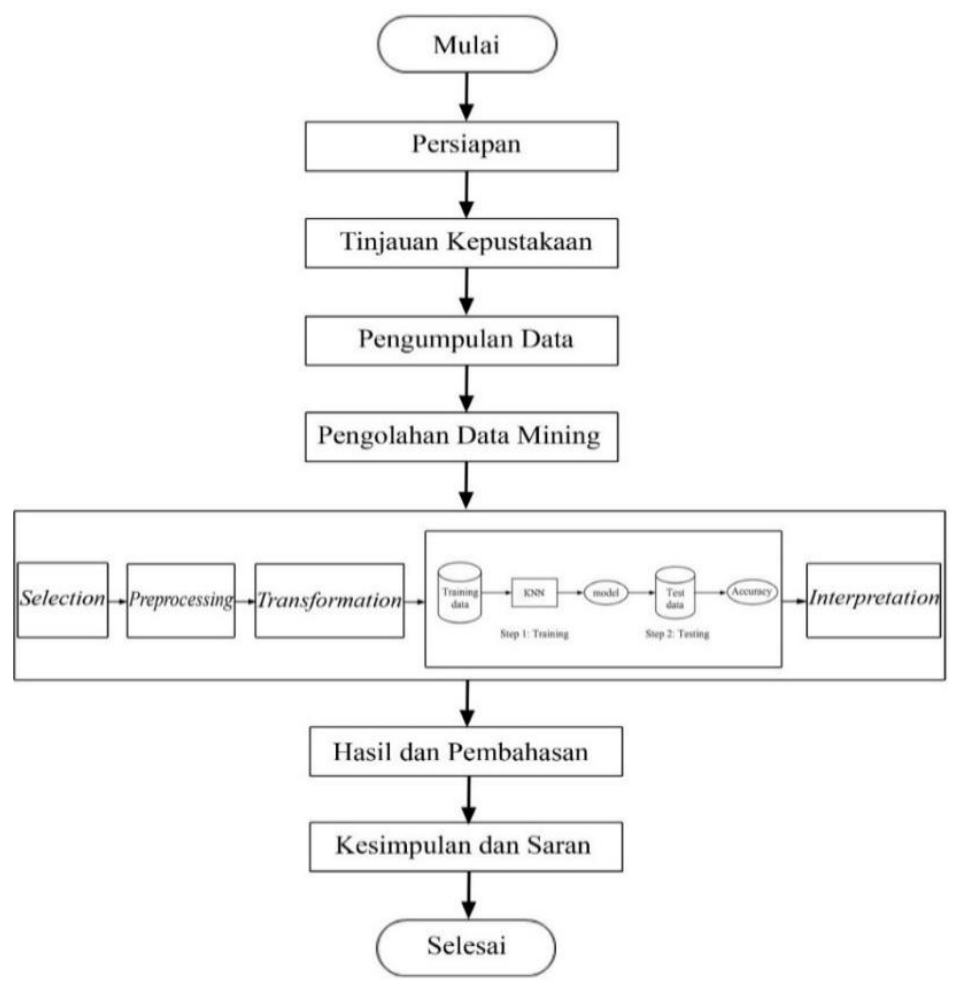

Gambar 1. Tahapan penelitian 
Tahapan penelitian yang dituangkan dalam diagram alir diatas menggambarkan proses penelitian yang akan dilaksanakan, yaitu :

a. Persiapan

Pada tahap ini menentukan objek yang akan diteliti yaitu data dari daftar kolektif hasil kuisioner PPLS (Program Perlindungan Sosial) Kelurahan Karya Jaya pada tahun 2017-2020 yang akan menjadi bahan untuk klasifikasi kelayakan penerima Bantuan Pangan Non Tunai (BPNT) Kelurahan Karya Jaya.

b. Tinjauan Kepustakaan

Pada tahap ini dilakukan telaah terhadap kriteria dalam klasifikasi penerima Bantuan Pangan Non Tunai (BPNT).

c. Pengumpulan Data

Proses pengumpulan data dilakukan dengan cara mengambil data dari daftar kolektif hasil Kuisioner PPLS (Program Perlindungan Sosial) tahun 2017-2020.

d. Pengolahan Data mining

Data yang telah dikumpulkan akan diolah sesuai dengan tahapan Knowledge Discovery in Databases (KDD).

e. Hasil dan Pembahasan

Pada tahap ini akan dijelaskan proses hasil dari data mining yang dilakukan dengan algoritma K-Nearest Neighbor (KNN).

f. Kesimpulan dan Saran

Membuat kesimpulan dari hasil penelitian dan saran untuk penelitian selanjutnya.

\section{HASIL DAN PEMBAHASAN}

\subsection{Hasil}

Setelah melakukan analisa dengan tahapan data mining untuk menghasilkan klasifikasi kelayakan terhadap penerima BPNT pada Kelurahan Karya Jaya dengan menggunakan algoritma K-Nearest Neighbor, maka hasil yang dicapai oleh peneliti ialah mengetahui bahwa dengan teknik klasifikasi maka dapat dilihat hasil prediksi KPM (Keluarga Penerima Manfaat) yang layak sebagai penerima BPNT pada tahun 2021. Dimana prediksi BPNT Kelurahan Karya Jaya pada tahun 2021 ialah sebanyak 511 penerima dengan tingkat Akurasi 75,79\%, Precision 76,17\%, Recall 89,24\%, F-measure 82,19\%, Serta dapat 
dilihat kategori penerima BPNT terbanyak ada pada SLS (Satuan Lingkungan Setempat) RW 005 yaitu 74 penerima.

Pada Gambar 2 dapat dilihat bahwa dari semua variabel yang digunakan terdapat variabel yang paling mempengaruhi dalam proses klasifikasi yaitu variabel sta_kis yang artinya 100\% KPM (Keluarga Penerima Manfaat) yang terdata sebagai penerima Kartu Indonesia Sehat (KIS) akan mendapat peluang yang besar menjadi penerima BPNT.

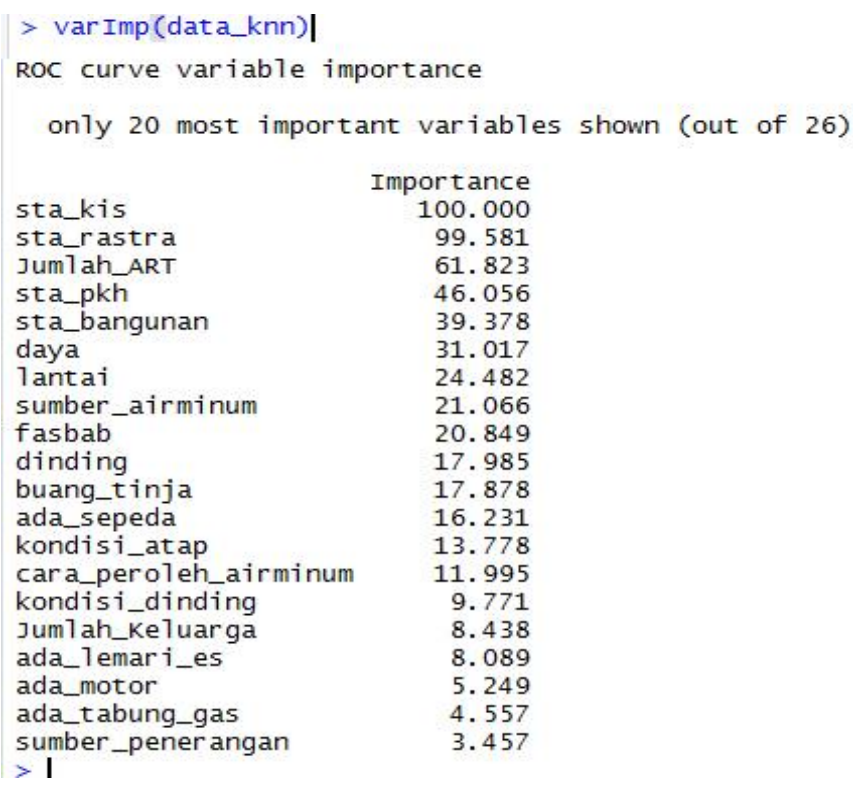

Gambar 2. Variabel Yang Paling Mempengaruhi

\subsection{Pembahasan}

Tahapan yang digunakan dalam pengolahan data mining pada penelitian ini, yaitu mengikuti tahapan Knowledge Discovery in Database (KDD) sebagai berikut :

\subsubsection{Data Selection}

Dataset yang digunakan ialah daftar Program Perlindungan Sosial Kelurahan Karya Jaya pada tahun 2017-2020 terdiri atas 71 variabel dan 3081 record. Sebelum dilakukan proses data mining pada proses ini dataset akan di reparasi yaitu menghilangkan variabel yang tidak dipakai ketika proses data mining. 
Variabel yang dipakai dalam proses klasifikasi penerima BPNT ini menggunakan Variabel dari Badan Pusat Statistik, Pemilihan variabel untuk proses klasifikasi penerima BPNT dapat dilihat pada Tabel 1.

Tabel 1. Keterangan Variabel

\begin{tabular}{|c|c|c|c|}
\hline No & VARIABEL & KETERANGAN & TIPE DATA \\
\hline 1 & Jumlah_Keluarga & $\begin{array}{l}\text { Jumlah Keluarga yang masuk } \\
\text { tanggungan kepala rumah tangga }\end{array}$ & Integer \\
\hline 2 & Jumlah_ART & Jumlah anggota rumah tangga & Integer \\
\hline 3 & sta_bangunan & $\begin{array}{l}\text { Status penguasaan bangunan tempat } \\
\text { tinggal yang ditempati }\end{array}$ & Ordinal \\
\hline 4 & luas_lantai & Luas Lantai ... $m^{2}$ & Integer \\
\hline 5 & lantai & Jenis lantai terluas & Ordinal \\
\hline 6 & dinding & Jenis dinding terluas & Ordinal \\
\hline 7 & kondisi_dinding & $\begin{array}{l}\text { Jika jenis dinding terluas berkode } 1 \text { atau } \\
2, \text { kondisi dinding }\end{array}$ & Ordinal \\
\hline 8 & Atap & Jenis atap terluas & Ordinal \\
\hline 9 & kondisi_atap & $\begin{array}{l}\text { Jika jenis atap terluas berkode 1,2,3,4, } \\
\text { atau 5, kondisi atap }\end{array}$ & Ordinal \\
\hline 10 & sumber_airminum & Sumber air minum & Ordinal \\
\hline 11 & $\begin{array}{l}\text { cara_peroleh_air } \\
\text { minum }\end{array}$ & Cara memperoleh air minum & Ordinal \\
\hline 12 & $\begin{array}{l}\text { sumber_penerang } \\
\text { an }\end{array}$ & Sumber penerangan utama & Ordinal \\
\hline 13 & Daya & Jika listrik PLN $(8 a=1)$, daya terpasang & Ordinal \\
\hline 14 & bb_masak & $\begin{array}{l}\text { Bahan bakar/enery utama untuk } \\
\text { memasak }\end{array}$ & Ordinal \\
\hline 15 & Fasbab & $\begin{array}{l}\text { Penggunaan fasilitas tempat buang air } \\
\text { besar }\end{array}$ & Ordinal \\
\hline 16 & buang_tinja & Tempat pembuangan akhir tinja & Ordinal \\
\hline 17 & ada_mobil & $\begin{array}{l}\text { Apakah rumah tangga memiliki sendiri } \\
\text { asset mobil }\end{array}$ & Ordinal \\
\hline 18 & ada_motor & $\begin{array}{l}\text { Apakah rumah tangga memiliki sendiri } \\
\text { asset motor }\end{array}$ & Ordinal \\
\hline 19 & ada_sepeda & $\begin{array}{l}\text { Apakah rumah tangga memiliki sendiri } \\
\text { asset sepeda }\end{array}$ & Ordinal \\
\hline 20 & ada_lemari_es & $\begin{array}{l}\text { Apakah rumah tangga memiliki sendiri } \\
\text { asset lemari es }\end{array}$ & Ordinal \\
\hline 21 & ada_tabung_gas & $\begin{array}{l}\text { Apakah rumah tangga memiliki sendiri } \\
\text { asset tabung gas }\end{array}$ & Ordinal \\
\hline
\end{tabular}




\begin{tabular}{|c|c|c|c|}
\hline No & VARIABEL & KETERANGAN & TIPE DATA \\
\hline 22 & sta_pkh & $\begin{array}{l}\text { Apakah rumah tangga menjadi peserta } \\
\text { program pkh }\end{array}$ & Ordinal \\
\hline 23 & sta_rastra & $\begin{array}{l}\text { Apakah rumah tangga menjadi peserta } \\
\text { program rastra }\end{array}$ & Ordinal \\
\hline 24 & sta_kis & $\begin{array}{l}\text { Apakah rumah tangga menjadi peserta } \\
\text { program kis }\end{array}$ & Ordinal \\
\hline 25 & sta_asuransi & $\begin{array}{l}\text { Apakah rumah tangga menjadi peserta } \\
\text { program asuransi }\end{array}$ & Ordinal \\
\hline 26 & sta_jamsostek & $\begin{array}{l}\text { Apakah rumah tangga menjadi peserta } \\
\text { program jamsostek } \\
\text { Keterangan: }\end{array}$ & Ordinal \\
\hline 27 & KETERANGAN & $\begin{array}{l}\text { 1. Penerima } \\
\text { 2. Bukan Penerima }\end{array}$ & Ordinal \\
\hline
\end{tabular}

Dalam penelitian ini pada awalnya terdapat 71 variabel kemudian setelah dilakukan seleksi data menjadi 27 variabel.

\subsubsection{Pre-Processing}

Dalam dataset penerima BPNT yang digunakan dalam penelitian ini, terdapat 3081 record atau tuple sebelum dilakukan proses pre-processing dan setelah dilakukan pre-processing menjadi 2748 record atau tuple.

\subsubsection{Transformation}

Pada tahap ini data yang telah dipilih akan diubah sehingga sesuai untuk proses data mining. Adapun attribute yang melalui proses transformasi sebagai berikut

1. luas_lantai

Pada attribute luas_lantai data akan diubah dari nilai integer menjadi ordinal sebagai berikut :

$\leq 8 \mathrm{~m}^{2}$ /orang $=1$;

$>8 \mathrm{~m}^{2} /$ orang $=2$.

Tabel 2. Transformasi Data luas_lantai

\begin{tabular}{cccc}
\hline $\begin{array}{c}\text { Data Awal } \\
\text { luas_lantai }\end{array}$ & Jumlah_ART & Luas_lantai/orang & $\begin{array}{c}\text { Konversi Data } \\
\text { Ordinal }\end{array}$ \\
\hline $14 \mathrm{~m}^{2}$ & 3 & $4,67 \mathrm{~m}^{2}$ & 1 \\
$45 \mathrm{~m}^{2}$ & 2 & $22,5 \mathrm{~m}^{2}$ & 2 \\
\hline
\end{tabular}


2. jumlah_keluarga

Pada attribute jumlah_keluarga tipe data akan diubah dari integer menjadi ordinal sebagai berikut:

Tabel 3. Transformasi Data jumlah_keluarga

\begin{tabular}{cc}
\hline Data Awal & Konversi Data Ordinal \\
\hline 1 & 1 \\
2 & 2 \\
3 & 3 \\
4 & 4 \\
\hline
\end{tabular}

3. jumlah_ART

Pada attribute jumlah_ART data akan diubah menjadi ordinal sebagai berikut:

Tabel 4. Transformasi Data jumlah_ART

\begin{tabular}{cc}
\hline Data Awal & Konversi Data Ordinal \\
\hline 3 & 2 \\
4 & 3 \\
5 & 3 \\
6 & 4 \\
7 & 4 \\
8 & 5 \\
9 & 5 \\
\hline
\end{tabular}

\subsubsection{K-Nearest Neighbor}

Berikut ini contoh perhitungan manual K-Nearest Neighbor dengan menggunakan data sample pada tahun 2017-2020 sebagai data training dan 2021 sebagai data testing.

Adapun langkah-langkah dari perhitungan K-Nearest Neighbor:

1. Penentuan nilai $K$. Pada penelitian ini nilai $K$ yang digunakan adalah $K=5$.

2. Hitung jarak antar data training dan data uji (test) dengan menggunakan perhitungan Euclidean Distance sebagai berikut :

$$
\mathrm{d}(x, y)=\sqrt{\sum_{i=1}^{n}\left(x_{i}-y_{i}\right)^{2}}
$$


Keterangan :

$$
\begin{aligned}
& \mathrm{d}(\mathrm{x}, \mathrm{y}) \quad=\text { Jarak Euclidean } \quad \mathrm{xi}=\text { Nilai data latih yang ke- } \\
& \text { yi } \quad=\text { Nilai data uji yang ke- in = Banyaknya data } \\
& =1,2,3, \ldots \mathrm{n}
\end{aligned}
$$

\begin{tabular}{|c|c|c|c|c|c|c|c|c|c|c|c|c|c|}
\hline 울 & 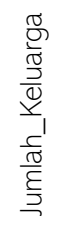 & 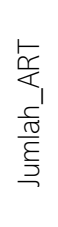 & 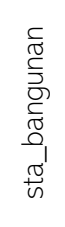 & 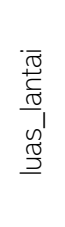 & 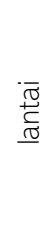 & 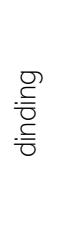 & 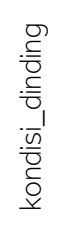 & & 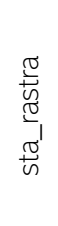 & $\begin{array}{l}\frac{n}{\bar{v}} \mid \\
\frac{\pi}{n}\end{array}$ & 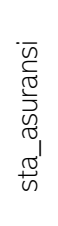 & 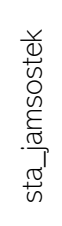 & 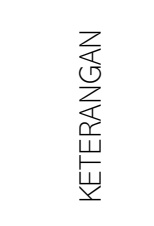 \\
\hline 1 & 1 & 2 & 2 & 2 & 8 & 3 & 2 & $\ldots$ & 3 & 2 & 4 & 2 & PENERIMA \\
\hline 2 & 1 & 4 & 1 & 2 & 8 & 3 & 2 & $\ldots$ & 3 & 1 & 4 & 2 & $\begin{array}{c}\text { BUKAN } \\
\text { PENERIMA }\end{array}$ \\
\hline 3 & 1 & 3 & 1 & 2 & 8 & 3 & 2 & $\ldots$ & 3 & 1 & 4 & 2 & PENERIMA \\
\hline 4 & 1 & 2 & 5 & 2 & 8 & 3 & 2 & $\ldots$ & 3 & 2 & 4 & 2 & $\begin{array}{c}\text { BUKAN } \\
\text { PENERIMA }\end{array}$ \\
\hline 5 & 1 & 3 & 1 & 1 & 6 & 1 & 2 & 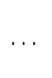 & 4 & 2 & 4 & 2 & $\begin{array}{c}\text { BUKAN } \\
\text { PENERIMA }\end{array}$ \\
\hline 6 & 1 & 3 & 3 & 2 & 8 & 3 & 2 & & 3 & 1 & 4 & 2 & PENERIMA \\
\hline 7 & 1 & 3 & 1 & 1 & 8 & 3 & 2 & $\ldots$ & 3 & 1 & 4 & 2 & PENERIMA \\
\hline 8 & 2 & 4 & 2 & 1 & 8 & 3 & 2 & $\ldots$ & 3 & 2 & 4 & 2 & PENERIMA \\
\hline 9 & 2 & 4 & 1 & 1 & 8 & 3 & 2 & $\ldots$ & 3 & 2 & 4 & 2 & PENERIMA \\
\hline 10 & 1 & 2 & 1 & 2 & 8 & 3 & 2 & & 3 & 1 & 4 & 2 & PENERIMA \\
\hline$\ldots$ & $\ldots$ & $\ldots$ & $\ldots$ & $\ldots$ & $\ldots$ & $\ldots$ & $\ldots$ & $\ldots$ & $\ldots$ & $\ldots$ & $\ldots$ & $\ldots$ & $\ldots$ \\
\hline $\begin{array}{c}205 \\
0\end{array}$ & 1 & 3 & 1 & 1 & 8 & 3 & 2 & $\ldots$ & 3 & 1 & 4 & 2 & PENERIMA \\
\hline
\end{tabular}

Tabel 5. Data Training

Tabel 6. Data Testing

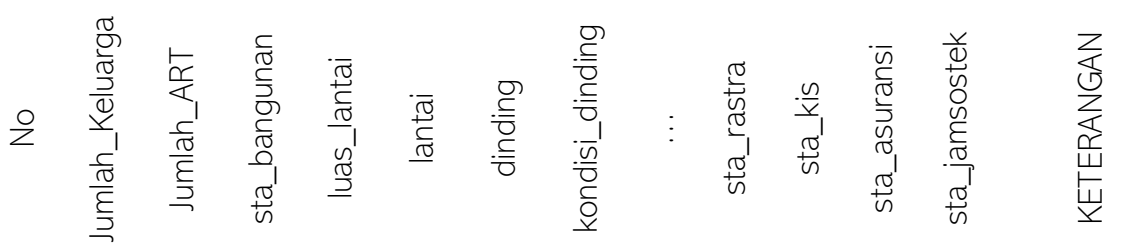

$\begin{array}{llllllllllllll}1 & 1 & 3 & 1 & 2 & 8 & 3 & 2 & \ldots & 3 & 2 & 4 & 2\end{array}$ 


$$
\begin{aligned}
d(1,1) & =\sqrt{(1-1)^{2}+(2-3)^{2}+(2-1)^{2}+\cdots+(4-4)^{2}+(2-2)^{2}} \\
& =\sqrt{(0)^{2}+(-1)^{2}+(1)^{2}+\ldots+(0)^{2}+(0)^{2}} \\
& =\sqrt{0+1+1+\cdots+0+0} \\
& =\sqrt{45} \\
& =6.70820393249937
\end{aligned}
$$

Jarak antara data training dan data uji (test) seterusnya dihitung menggunakan

\begin{tabular}{|c|c|c|c|c|c|c|c|c|c|}
\hline 1 & 1 & 2 & 2 & $\ldots$ & 2 & 4 & 2 & PENERIMA & 6.70820393249937 \\
\hline 2 & 1 & 4 & 1 & $\cdots$ & 1 & 4 & 2 & $\begin{array}{c}\text { BUKAN } \\
\text { PENERIMA }\end{array}$ & 7.41619848709566 \\
\hline 3 & 1 & 3 & 1 & $\ldots$ & 1 & 4 & 2 & PENERIMA & 6.6332495807108 \\
\hline 4 & 1 & 2 & 5 & $\ldots$ & 2 & 4 & 2 & $\begin{array}{c}\text { BUKAN } \\
\text { PENERIMA }\end{array}$ & 8.94427190999916 \\
\hline 5 & 1 & 3 & 1 & . & 2 & 4 & 2 & $\begin{array}{c}\text { BUKAN } \\
\text { PENERIMA }\end{array}$ & 7.61577310586391 \\
\hline 6 & 1 & 3 & 3 & $\cdots$ & 1 & 4 & 2 & PENERIMA & 7.34846922834953 \\
\hline 7 & 1 & 3 & 1 & $\ldots$ & 1 & 4 & 2 & PENERIMA & 6.48074069840786 \\
\hline 8 & 2 & 4 & 2 & $\ldots$ & 2 & 4 & 2 & PENERIMA & 3.74165738677394 \\
\hline 9 & 2 & 4 & 1 & $\ldots$ & 2 & 4 & 2 & PENERIMA & 6.78232998312527 \\
\hline 10 & 1 & 2 & 1 & $\cdots$ & 1 & 4 & 2 & PENERIMA & 8.42614977317636 \\
\hline$\ldots$ & $\ldots$ & $\ldots$ & $\ldots$ & $\ldots$ & $\cdots$ & $\ldots$ & $\ldots$ & $\ldots$ & $\cdots$ \\
\hline $\begin{array}{c}205 \\
0\end{array}$ & 1 & 3 & 1 & $\ldots$ & 2 & 4 & 2 & $\begin{array}{c}\text { BUKAN } \\
\text { PENERIMA }\end{array}$ & 6.85565460040104 \\
\hline
\end{tabular}
cara yang sama. Hasil perhitungan Euclidean distance secara manual seperti pada Tabel 7.

Tabel 7. Hasil Perhitungan Euclidean Distance

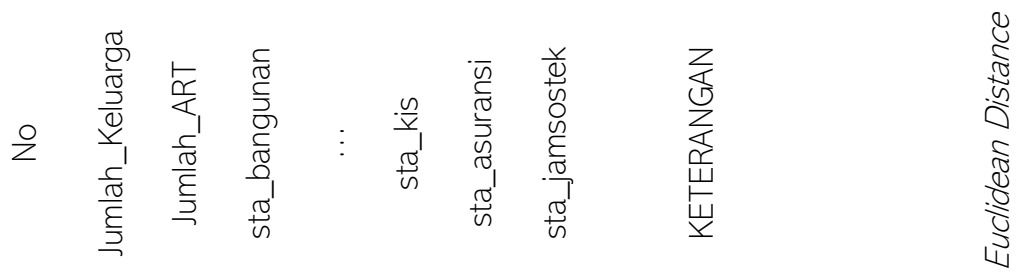

3. Setelah diketahui jarak antara data baru dengan data latih, maka data diurutkan berdasarkan euclidean distance terkecil ke terbesar. Semakin kecil euclidean distance berarti jarak antar data semakin dekat. 
Tabel 8. Hasil Perhitungan Euclidean Distance Yang Telah Diurutkan

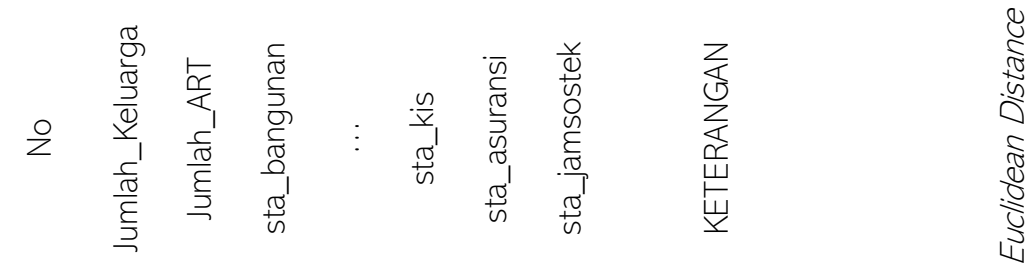

\begin{tabular}{|c|c|c|c|c|c|c|c|c|c|}
\hline 531 & 1 & 3 & 1 & $\ldots$ & 2 & 4 & 2 & $\begin{array}{c}\text { BUKAN } \\
\text { PENERIMA }\end{array}$ & 1.73205080756888 \\
\hline $\begin{array}{c}181 \\
2\end{array}$ & 1 & 4 & 1 & $\cdots$ & 1 & 4 & 2 & PENERIMA & 1.73205080756888 \\
\hline 274 & 1 & 2 & 1 & $\ldots$ & 2 & 4 & 2 & $\begin{array}{c}\text { BUKAN } \\
\text { PENERIMA }\end{array}$ & 2.00000000000000 \\
\hline 743 & 1 & 2 & 1 & $\cdots$ & 2 & 4 & 2 & $\begin{array}{c}\text { BUKAN } \\
\text { PENERIMA }\end{array}$ & 2.00000000000000 \\
\hline $\begin{array}{c}142 \\
6\end{array}$ & 1 & 2 & 1 & $\ldots$ & 2 & 4 & 2 & $\begin{array}{l}\text { BUKAN } \\
\text { PENERIMA }\end{array}$ & 2.00000000000000 \\
\hline 526 & 3 & 3 & 1 & $\cdots$ & 1 & 4 & 2 & PENERIMA & 2.44948974278318 \\
\hline 661 & 1 & 2 & 1 & $\ldots$ & 2 & 4 & 2 & $\begin{array}{l}\text { BUKAN } \\
\text { PENERIMA }\end{array}$ & 2.44948974278318 \\
\hline $\begin{array}{c}108 \\
0\end{array}$ & 1 & 2 & 1 & $\ldots$ & 2 & 4 & 2 & $\begin{array}{c}\text { BUKAN } \\
\text { PENERIMA }\end{array}$ & 2.44948974278318 \\
\hline $\begin{array}{c}141 \\
6\end{array}$ & 1 & 2 & 3 & $\ldots$ & 2 & 4 & 2 & PENERIMA & 2.44948974278318 \\
\hline $\begin{array}{l}202 \\
8\end{array}$ & 1 & 5 & 1 & & 2 & 4 & 2 & $\begin{array}{c}\text { BUKAN } \\
\text { PENERIMA }\end{array}$ & 2.64575131106459 \\
\hline$\ldots$ & $\ldots$ & $\ldots$ & $\ldots$ & $\ldots$ & $\ldots$ & $\ldots$ & $\ldots$ & $\ldots$ & $\ldots$ \\
\hline $\begin{array}{c}195 \\
7 \\
\end{array}$ & 1 & 3 & 1 & $\ldots$ & 2 & 4 & 2 & $\begin{array}{c}\text { BUKAN } \\
\text { PENERIMA }\end{array}$ & 11.13552872566 \\
\hline
\end{tabular}

4. Menentukan kelompok data hasil uji berdasarkan label mayoritas dari $\mathrm{k}$ tetangga terdekat. Karena nilai $k=5$, maka yang diambil 5 terkecil.

Tabel 9. Peringkat Data dengan $\mathrm{K}=5$

\begin{tabular}{|c|c|c|c|c|}
\hline 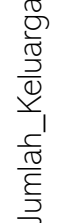 & 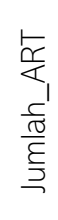 & 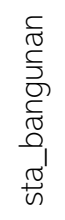 & $\vdots \frac{\frac{\omega}{x}}{\frac{\sigma}{\omega}}$ & 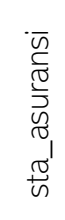 \\
\hline
\end{tabular}




\begin{tabular}{|c|c|c|c|c|c|c|c|c|c|}
\hline 531 & 1 & 3 & 1 & $\cdots$ & 2 & 4 & 2 & $\begin{array}{c}\text { BUKAN } \\
\text { PENERIMA }\end{array}$ & 1.73205080756888 \\
\hline $\begin{array}{c}181 \\
2\end{array}$ & 1 & 4 & 1 & $\cdots$ & 1 & 4 & 2 & PENERIMA & 1.73205080756888 \\
\hline 274 & 1 & 2 & 1 & $\ldots$ & 2 & 4 & 2 & $\begin{array}{c}\text { BUKAN } \\
\text { PENERIMA }\end{array}$ & 2.00000000000000 \\
\hline 743 & 1 & 2 & 1 & $\cdots$ & 2 & 4 & 2 & $\begin{array}{c}\text { BUKAN } \\
\text { PENERIMA }\end{array}$ & 2.00000000000000 \\
\hline $\begin{array}{c}142 \\
6 \\
\end{array}$ & 1 & 2 & 1 & $\cdots$ & 2 & 4 & 2 & $\begin{array}{c}\text { BUKAN } \\
\text { PENERIMA }\end{array}$ & 2.00000000000000 \\
\hline
\end{tabular}

\subsection{Implementasi RStudio}

Hasil prediksi dengan RStudio dapat dilihat pada Gambar 3. Pada grafik tersebut dapat dilihat bahwa hasil prediksi penerima Bantuan Pangan Non Tunai ada pada SLS RW 005 dengan hasil prediksi 74 KPM.

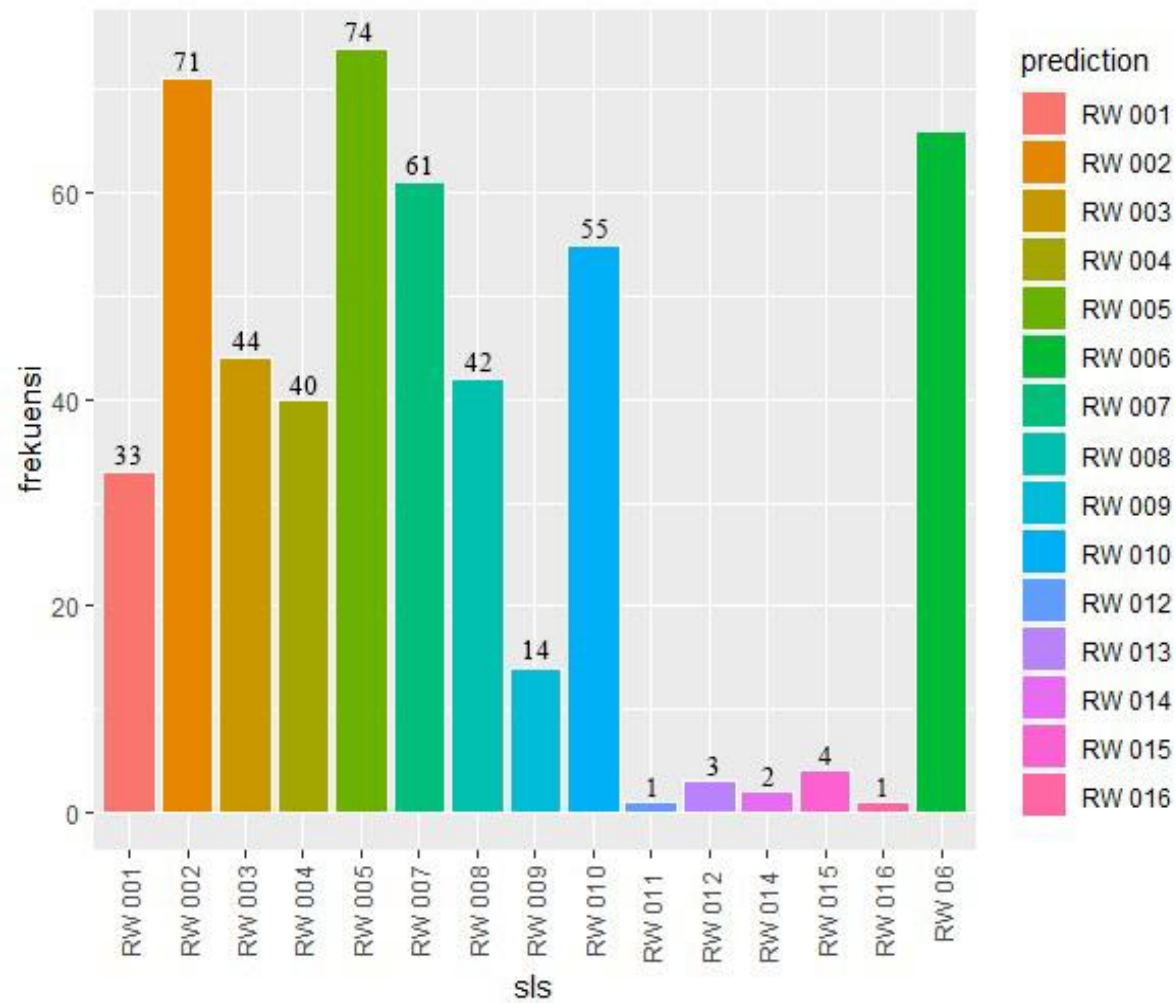

Gambar 3. Grafik Hasil Prediksi Berdasarkan Kategori SLS 


\section{KESIMPULAN}

Berdasarkan hasil dan analisis data yang telah dipaparkan, maka dapat disimpulkan bahwa :

1. Teknik klasifikasi data mining yaitu dengan menggunakan algoritma KNearest Neighbor dapat digunakan untuk prediksi penerima BPNT pada tahun 2021.

2. K optimal untuk melakukan pemodelan adalah $\mathrm{k}=5$ dengan accuracy $76,91 \%$.

3. Prediksi penerima BPNT Kelurahan Karya Jaya pada tahun 2021 adalah sebanyak 511 penerima dengan kategori penerima BPNT terbanyak ada pada SLS RW 005 yaitu 74 penerima.

4. Tingkat akurasi dari hasil Prediksi penerima Bantuan Pangan Non Tunai (BPNT) Kelurahan Karya Jaya pada tahun 2021 adalah 75,79\%.

5. Variabel yang paling mempengaruhi proses klasifikasi adalah sta_kis.

\section{DAFTAR PUSTAKA}

[1] P. Maharani, "Pedoman Umum Bantuan Pangan Nontunai 2019," pp. 1 174, 2019, [Online]. Available: https://www.kemsos.go.id/uploads/topics/15767284433221.pdf.

[2] C. A. Sugianto and F. R. Maulana, "Algoritma Naïve Bayes Untuk Klasifikasi Penerima Bantuan Pangan Non Tunai ( Studi Kasus Kelurahan Utama )," Techno.Com, vol. 18, no. 4, pp. 321-331, 2019, doi: 10.33633/tc.v18i4.2587.

[3] F. S. Jumeilah, "Klasifikasi Opini Masyarakat Terhadap Jasa Ekspedisi JNE dengan Naïve Bayes," J. Sist. Inf. Bisnis, vol. 8, no. 1, p. 92, 2018, doi: 10.21456/vol8iss1 pp92-98.

[4] F. Liantoni, "Klasifikasi Daun Dengan Perbaikan Fitur Citra Menggunakan Metode K-Nearest Neighbor," J. Ultim., vol. 7, no. 2, pp. 98-104, 2016, doi: $10.31937 /$ ti.v7i2.356.

[5] N. Bhatia and Vandana, "Survey of Nearest Neighbor Techniques," vol. 8, no. 2, pp. 302-305, 2010, [Online]. Available: http://arxiv.org/abs/1007.0085. 